\title{
Governance models for nature-based solutions: Seventeen cases from Germany
}

\author{
Aude Zingraff-Hamed (ㅇ, Frank Hüesker, Christian Albert, \\ Mario Brillinger, Joshua Huang, Gerd Lupp, Sebastian Scheuer, \\ Mareen Schlätel, Barbara Schröter
}

\begin{abstract}
Nature-based solutions (NBS) for mitigating climate change are gaining popularity. The number of NBS is increasing, but research gaps still exist at the governance level. The objectives of this paper are (i) to give an overview of the implemented NBS for flood risk management and mitigation in Germany, (ii) to identify governance models that are applied, and (iii) to explore the differences between these models. The results of a hierarchical clustering procedure and a qualitative analysis show that while no one-size-fits-all governance model exists, polycentricism is an important commonality between the projects. The study concludes by highlighting the need for further research on traditional governance model reconversion and paradigm changes. We expect the findings to identify what has worked in the past, as well as what is important for the implementation of NBS for flood risk management in future projects.
\end{abstract}

Keywords Financing instruments - Flood risk mitigation Institutional structures - Polycentric governance ·

River Management $\cdot$ Stakeholder participation

\section{INTRODUCTION}

Change in climate patterns cause the increase of extreme hydro-meteorological events which results in more floods and droughts (Beniston 2007; De Paola et al. 2018; EC 2020). While flooding is a natural process that is essential for biological health and riverine functions (Junk et al. 1989), it also represents one of the most common natural

Electronic supplementary material The online version of this article (https://doi.org/10.1007/s13280-020-01412-x) contains supplementary material, which is available to authorized users. hazards that lead to catastrophes in Europe (EEA 2016). Floods have caused not only damages and disruptions, but also various health effects including deaths, injuries, poor sanitation, and poor water quality (Hajat et al. 2005; Doocy et al. 2013). Hydro-meteorological experts estimate that climate change may induce more flood risk due to an increase in the intensity and frequency of extreme weather events (EEA 2016). Annual monetary damages from flooding in Europe is expected to rise from 6 billion to about 108 billion USD by 2080 if no further prevention and adaptation measures are implemented (EC 2014).

To address growing flooding risk and related impacts, nature-based solutions (NBS) are becoming more popular as an effective complement or partially replacement of conventional technical approaches such as static flood protection infrastructures (UN 2018). The benefits of intact ecosystems is since early twenty-first century recognized (Cohen-Shacham et al. 2016) and some concepts such as "more room for the river" in France, the Netherlands, and Germany acknowledged the benefits of dynamic environmental processes. However, in the past two decades, the implementation of ecosystem-based management has become more popular worldwide, and the need for consistent terminology has resulted in the use of the term NBS. NBS can consist of different levels of natural components (Eggermont et al. 2015). For flood risk mitigation, examples of NBS include providing more space for rivers, e.g., Nesttunvassdraget in Norway (CoB 2007), revitalizing floodplains, e.g., Grand Park Garonne in France (Van de Kreek and Etienne 2012) establishing green infrastructure in cities, e.g., The Green Ring, Antwerpen in Belgium (Haine 2014), and implementing decentralized rainwater management, e.g., Rewitalizacja rzeki Białej in Poland (Sadowska-Dubicka 2015). NBS are defined as "actions which are inspired by, supported by or copied from nature" 
(EC 2015b), or more specifically, actions that (i) alleviate a well-defined societal challenge, (ii) utilize ecosystem processes, and (iii) are embedded within viable governance models (Albert et al. 2019). Governance models are ideal governance types explaining the interrelation of different actors and institutions in the context of rules and rulemaking systems to coordinate interdependencies and hierarchical market and community management (Wamsler et al. 2017).

The concept of NBS has recently gained attention in science and public policy (Nesshöver et al. 2017; Frantzeskaki et al. 2019) following its introduction by the International Union for Conservation of Nature (CohenShacham et al. 2016, 2019) and the European Union (EU). A large number of long-term research projects have recently been funded (EC 2015a, b), such as Physicos ${ }^{1}$ and ReConect ${ }^{2}$. A common strategy of those projects is to stimulate transdisciplinary research and to optimize and upscale pilot solutions to other sites while financially supporting implementation and providing governance support to enhance collaborative planning. Increased efforts have been undertaken recently to document and synthesize cases of NBS application in online databases (e.g., Oppla ${ }^{3}$ ). They aim to cross-fertilize and are useful for extracting technical and societal knowledge from success stories and cases that are recognized as good practice.

Unfortunately, the number of NBS is still low and implementations are often slowed down by barriers in governance (Kabisch et al. 2016; Ershad Sarabi et al. 2019). This indicates that investigating governance models may be a key to learning about more effective NBS implementation. Presently, there is little comparative research on NBS governance. Furthermore, because of different policy frameworks and local societal challenges, comparison and upscaling of research results are very limited (exception Martin 2019). Study showed that different water governance culture exist between the EU countries and that while EU directives highly influence the EU member policy, its incorporation in national law and its implementation vary between the countries and cause bias in regional governance comparison (Zingraff-Hamed et al. 2017b). Governance models have been mostly investigated in theoretical terms (Kooiman 2003; Treib et al. 2007), in the context of environmental policy (Arnouts et al. 2012), governance of ecosystem services (Vatn 2010; Schröter et al. 2019), and water governance (Pahl-Wostl 2015, 2019), but not in the context of NBS and not in a systematic way.

\footnotetext{
${ }^{1}$ www.phusicos.eu.

2 www.reconect.eu.

${ }^{3}$ https://oppla.eu/case-study-finder.
}

Consequently, our research question is as follows: Which governance models led to NBS implementation for flood risk management and mitigation? Specifically, our objectives are (i) to give an overview of the implemented NBS for mitigating flood risk in Germany, focusing on their governance models, (ii) to identify governance models that are applied in implemented cases, and (iii) to explore the differences between the models that are applied, in order to discuss future water governance challenges and to formulate recommendations for further implementation of NBS. In order to investigate the implementation of NBS in more detail from a governance perspective while avoiding comparison bias caused by policy variability, we decided to conduct an analysis that focused on Germany. As a federal state, Germany is characterized by a hierarchical share of competencies and state governments of the 16 states are responsible for policy implementation (Jänicke et al. 2001; Schroeter 2018). The state governments have much flexibility in the NBS planning process making Germany an interesting field for investigation of the design and implementation of NBS under different regional governance models (e.g., Newig et al. 2016). The results from our analysis are expected to give insights for implementing NBS in Germany and all around the globe.

\section{MATERIALS AND METHODS}

The methodology that we used in our analytical framework consists of the identification of predictor variables for the identification of key governance features, case selection and data collection, and the subsequent analysis of cases related to key governance features and their interpretation (Fig. 1).

\section{Selection of predictors}

To identify relevant variables for the governance analysis, we first identified and reviewed relevant literature. A preliminary list of variables was discussed during a workshop in February 2019 with seven NBS governance researchers from PlanSmart, Rivercare, Phusicos and ReConect. This result of this workshop was a list of twelve governance features, from which six were specifically selected (framing and implementing organizational structures, project coordination, participation level, institutional setting, financing model, and property rights constellation) because of their importance and potential for further analysis. In a second workshop, the working group further detailed the six selected governance features and categorized them by a number of possible predictor variables. For each variable, a characteristic question was formulated to simplify the 


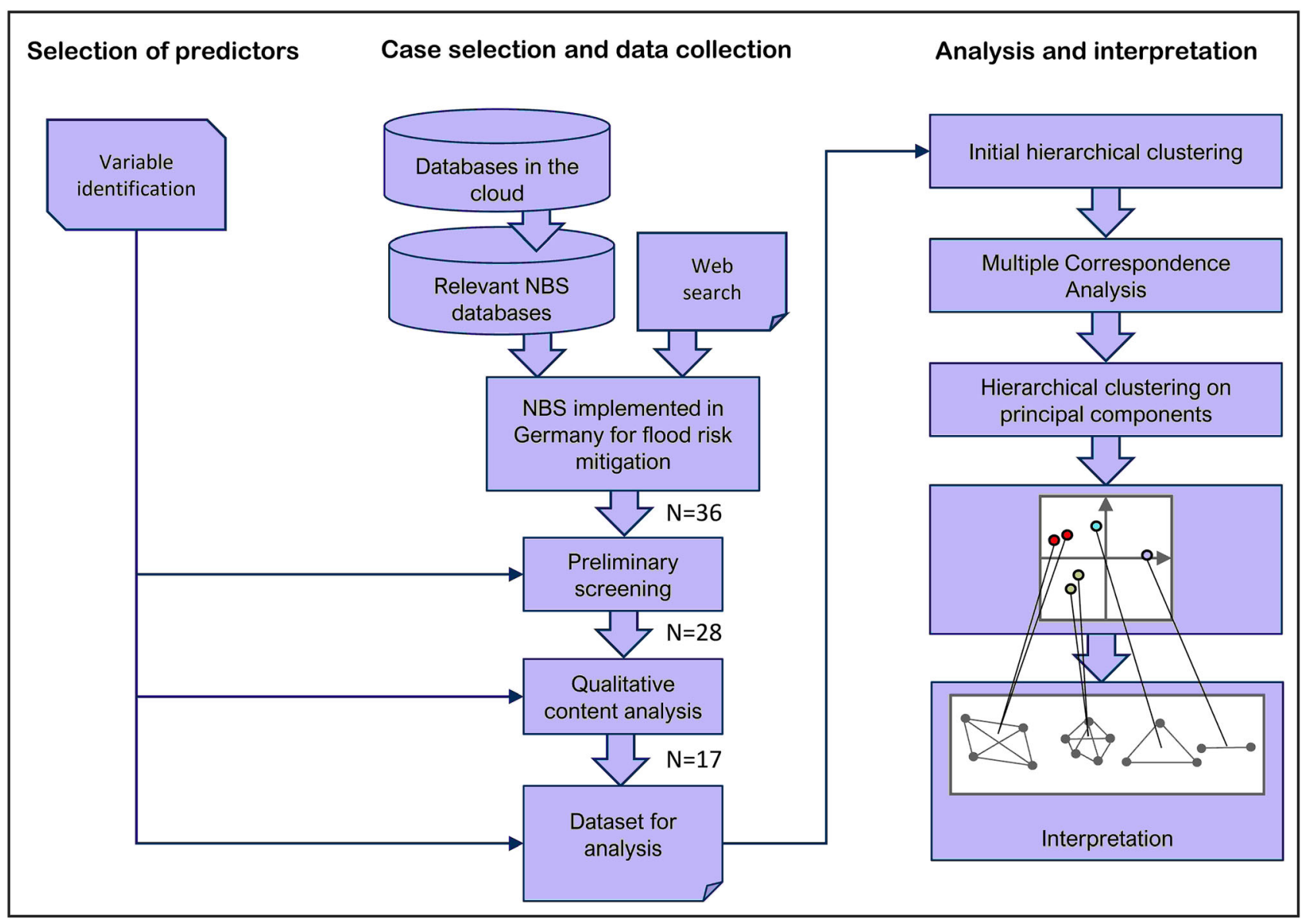

Fig. 1 Methodology outlining the analytical framework of the case study

subsequent data collection. For most variables, we defined a selection of qualitative and quantitative list of modalities (Table S1).

\section{Case selection and data collection}

We identified successfully implemented NBS for flood risk mitigation in Germany by querying existing NBS databases developed by several EU funded research projects in order to document the best practices of NBS implementation. An online search (June 2019, terms applied: "Nature-based solutions" AND "database") identified 59 relevant NBS databases. Then, they were filtered for German NBS for flood mitigation. We added to the selection German cases of the ongoing EU Horizon 2020 funded research projects. Then, we screened the results to identify cases with available data on governance. Cases without information or cases with insufficient information were excluded. Then, we screened the 28 remaining cases in the form of a qualitative content analysis (Mayring 2007) on project documentation, related press releases, project descriptions, case website contents, publications of scientific monitoring and articles available online. If information for few variables could not be found online, we contacted the person in charge for the respective projects for the missing information. For two cases, a full telephone interview was needed to gather the requested information. For ten cases, information could not be collected because either staff turnover did not allow us to contact the person in charge of the project, and the staff was not able to provide the necessary information or we were not able to reach a person in charge of the project by e-mail or phone. 17 cases (Fig. 2 and Table 1) could be fully documented for analysis and interpretation.

\section{Data analysis and interpretation}

The collected project data were transferred into a spreadsheet and prepared for statistical analysis by coding variables to numeric values (Table S1). Variables for which there was no information found were excluded from the analysis. The three variables that were excluded were coordination procedures, exchange platforms to support the participatory process, and participation process intensity 


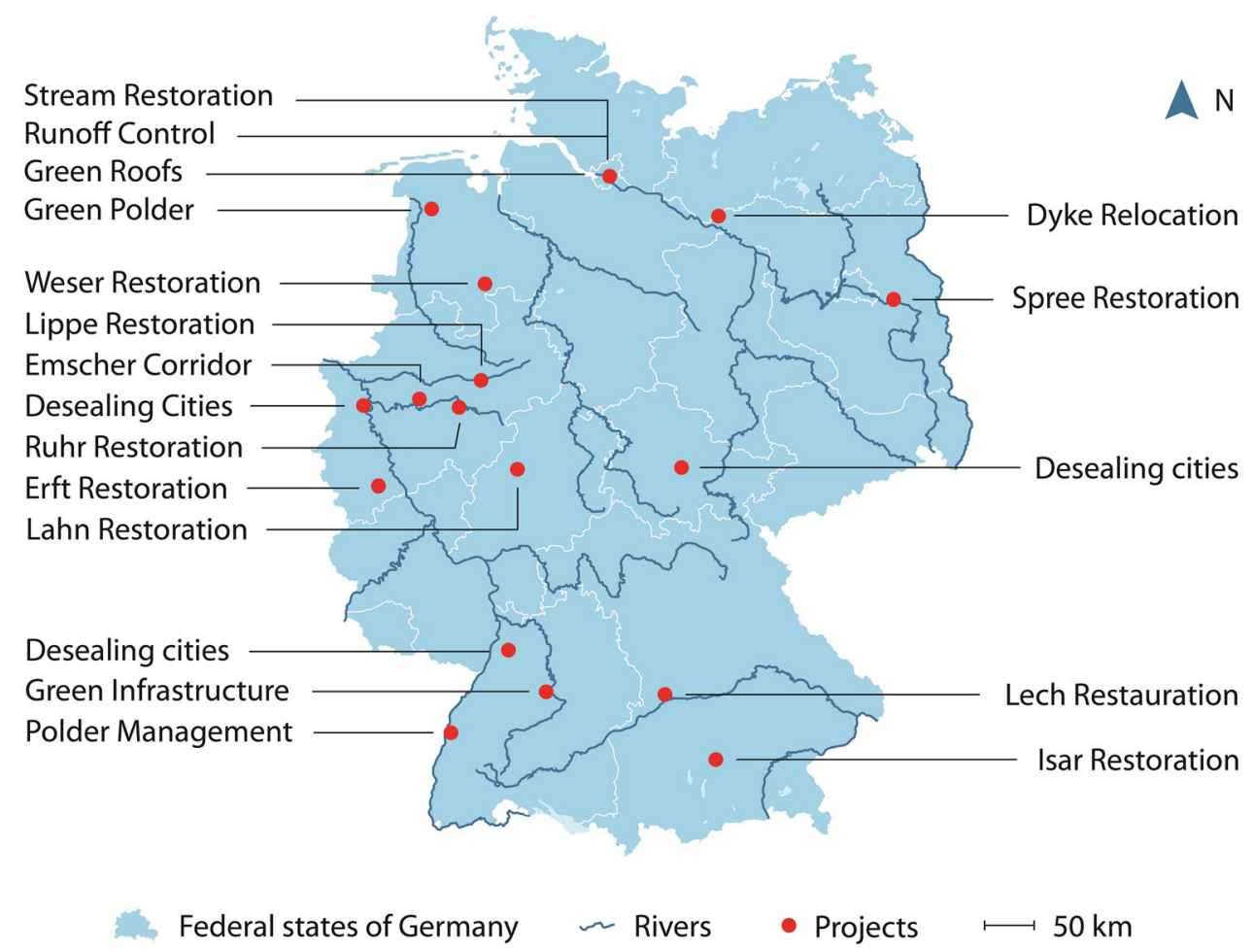

Fig. 2 Location of the selected case sites

and frequency. The codified data set was then assessed by applying exploratory multivariate data analysis using $\mathrm{R}$ version 3.6.2 in order to identify patterns and similarities across the cases $(p<0.05)$.

First, an agglomerative bottom-up hierarchical clustering algorithm was used for an initial identification of groups of similar cases. Hierarchical clustering was chosen as it is commonly considered suitable for smaller sample sizes. The dissimilarity matrix for clustering of cases is computed as the Gower distance metric (Gower 1971) which is suitable for mixed-type (categorial and numeric) data (Maechler et al. 2019). The complete linkage criterion was applied.

Then, a Multiple Correspondence Analysis (MCA) was applied to uncover the underlying structure of the data, i.e., the combinations of, and association between factors that govern the dissimilarity of cases in the groups identified and to subsequently describe and refine them. MCA is well suited for the determination of associations between categorial data (Greenacre 2006; Husson et al. 2017). MCA is commonly used for the identification of groups of individuals with similar profiles, e.g., in answer patterns of surveys, as well as to elicit associations between variable categories. The MCA was applied to the full data set. The categorical variables were included as explanatory variables, and numerical variables were included as supplementary information. The first three principal components chosen cumulatively account for about $40 \%$ of the variance in the data. The first component alone accounts for about $15 \%$ of variance. The second and third dimension, account for about $13.2 \%$ and $11.6 \%$, respectively.

Next, in order to refine the initial cluster findings, the cases were subsequently clustered using hierarchical clustering on principal components (HCPC) (Le et al. 2008) using k-means method to allow agglomerative clustering of multivariate data with different metric and structured into themes (Husson et al. 2017). Thus, the most descriptive predictors were identified for each cluster of governance models. Finally, the identified types of governance models were qualitatively compared to existing types of governance models defined in the literature.

\section{RESULTS}

The 17 cases (Fig. 2 and Table 1) showed a broad spectrum of NBS ranging from river restoration to green roofs. Only one of the NBS served a single goal, while the rest had multiple purposes. More than the half of the projects were in the framework of city governments ( 9 of 17 cases), but most of the NBS resulted from a cross-sectorial decision process (12 of 17 cases). Most of the projects have been implemented under the lead of the city $(N=7)$ or regional $(N=6)$ government. Information on project costs were 
Table 1 Overview of the selected case sites

\begin{tabular}{|c|c|c|c|c|}
\hline Full Title (including location) & $\begin{array}{l}\text { Short Title (for } \\
\text { figures and } \\
\text { tables) }\end{array}$ & Year & $\begin{array}{l}\text { Cost } \\
\text { (USD) }\end{array}$ & Description \\
\hline $\begin{array}{l}\text { Polder Management in Altenheim, Baden- } \\
\text { Wuertemberg }\end{array}$ & $\begin{array}{l}\text { Polder } \\
\quad \text { Management }\end{array}$ & 1987 & $\begin{array}{l}773 \\
185\end{array}$ & $\begin{array}{l}\text { Project improved the riverine ecological functionality } \\
\text { and created floodable space dedicated to recreational } \\
\text { uses. Implemented measures included floodplain } \\
\text { restoration and management, the restoration and } \\
\text { reconnection of seasonal streams, the reconnection of } \\
\text { oxbows, and the implementation of forest riparian } \\
\text { buffers. Challenging issues were forest management, } \\
\text { rising groundwater levels and potential increase of } \\
\text { mosquito population }\end{array}$ \\
\hline $\begin{array}{l}\text { Ruhr River Restoration in Binnerfeld, } \\
\text { Arnsberg-Neheim, North Rhine-Westphalia }\end{array}$ & $\begin{array}{l}\text { Ruhr } \\
\text { Restoration }\end{array}$ & 2006-2011 & $\begin{array}{r}1215 \\
005\end{array}$ & $\begin{array}{l}\text { Project was implemented on a total river length of } \\
4.5 \mathrm{~km} \text { to stimulate river dynamics, to improve its } \\
\text { ecological status and structural diversity as well as } \\
\text { flood protection. Measures included the removal of } \\
\text { bank fixation to initiate bank-side erosion, the } \\
\text { creation of flood-prone areas, the widening of the } \\
\text { river bed, the creation of side arms, the restructuring } \\
\text { of the river bed and banks by sediment addition and } \\
\text { the placement of large pieces of wood }\end{array}$ \\
\hline Lahn River Restoration in Cölbe, Hesse & $\begin{array}{l}\text { Lahn } \\
\quad \text { Restoration }\end{array}$ & 2000 & - & $\begin{array}{l}\text { Project intended to improve the river hydro- } \\
\text { morphological status and functions by removing bank } \\
\text { fixation, initiating bank-side erosion, creating side } \\
\text { arms and restructuring of river bed and banks }\end{array}$ \\
\hline $\begin{array}{l}\text { Lech River Restoration in Donauwörth, } \\
\text { Augsburg, Bavaria }\end{array}$ & $\begin{array}{l}\text { Lech } \\
\quad \text { Restoration }\end{array}$ & Since 2013 & $\begin{array}{l}966 \\
481\end{array}$ & $\begin{array}{l}\text { The project intends to improve the ecological status and } \\
\text { functions of the river Lech from the south of } \\
\text { Augsburg to the mouth of the river. The regional } \\
\text { water management authority in charge uses a Living } \\
\text { Lab approach to include various stakeholders and } \\
\text { citizens in the development of suitable and widely } \\
\text { accepted solutions }\end{array}$ \\
\hline $\begin{array}{l}\text { 'Living Lab Deusenberg to the Huckarde' in } \\
\text { Dortmund, North Rhine-Westphalia }\end{array}$ & $\begin{array}{l}\text { Emscher } \\
\text { Corridor }\end{array}$ & 2018-2023 & $\begin{array}{r}1300 \\
055\end{array}$ & $\begin{array}{l}\text { Besides creating green infrastructure with multiple } \\
\text { benefits, one central aspect of this project is also rain } \\
\text { water management and reducing rainwater runoff. } \\
\text { The project includes community-based urban farms } \\
\text { and gardens, food forests, a permaculture orchard and } \\
\text { the introduction of pollinator friendly plants using a } \\
\text { Living Lab approach and involving citizens for } \\
\text { monitoring }\end{array}$ \\
\hline $\begin{array}{l}\text { Wetland Restoration at Duemmer Lake, } \\
\text { Osnabrück, Lower-Saxony }\end{array}$ & $\begin{array}{l}\text { Weser } \\
\text { Restoration }\end{array}$ & 2007-2012 & $\begin{array}{r}3424 \\
105\end{array}$ & $\begin{array}{l}\text { The wetlands were restored due to the European } \\
\text { Development Fund in order to address the Habitats } \\
\text { Directive, and Birds Directive. Measures } \\
\text { implemented in } 2007 \text { and } 2012 \text { included the } \\
\text { restoration of meadows and pastures, reduced tillage, } \\
\text { and a reduced stocking density. A wide variety of } \\
\text { stakeholders were involved in the implementation } \\
\text { process, ranging from nature conservation agencies } \\
\text { and NGO's, as well as water managers to local } \\
\text { farmers }\end{array}$ \\
\hline $\begin{array}{l}\text { Lippe Floodplain Restoration in Klostermersch } \\
\text { Lippstadt, North Rhine-Westphalia }\end{array}$ & $\begin{array}{l}\text { Lippe } \\
\quad \text { Restoration }\end{array}$ & 1991-1997 & $\begin{array}{r}2209 \\
100\end{array}$ & $\begin{array}{l}\text { Project intended to stop incision of the river and to } \\
\text { improve the ecological status of the river. Starting in } \\
\text { 1991, the intensity of the land use was gradually } \\
\text { reduced. Fortified embankments were lifted and the } \\
\text { river was broadened to } 42 \text { m to permit natural } \\
\text { dynamics. To stimulate the development of rich } \\
\text { structured half-open floodplain landscapes, grazing } \\
\text { with Heck cattle was introduced. Restoration } \\
\text { measures were discussed with different interest } \\
\text { groups and private land owners were invited to } \\
\text { participate }\end{array}$ \\
\hline
\end{tabular}


Table 1 continued

\begin{tabular}{llll}
\hline Full Title (including location) & $\begin{array}{l}\text { Short Title (for } \\
\text { figures and } \\
\text { tables) }\end{array}$ & $\begin{array}{l}\text { Cost Description } \\
\text { (USD) }\end{array}$
\end{tabular}

Spree River Restoration at

Mönchwinkel Grünheide, Brandenburg

'Nature in Grey Zones' in Duisburg (North

Rhine-Westphalia), Erfurt ( Thuringia) and

Wiesloch ( Baden-Wuertemberg)

Erft River Restoration in Weilerswist, North Rhine-Westphalia

Green Roof Strategy in Hamburg

Inner-City-Discharge Program in Hamburg

Runoff Control 2009

'Stream Action Day' in Hamburg

Flood Protection and Nature Conservation at Polder Holter-Hammrich, Leer, Lower-

Saxony

Elbe Dyke Relocation in Lenzen, Brandenburg Dyke Relocation

2002-2011 14359 In this project, a dike was relocated, reconnecting the 150

1855 Project aimed to stabilize the riverbed and improve

644 riverine ecological status. Side arm meanders were reconnected to the river to slow down flows, reduce incision and enhance the ecological qualities of the river. The project was coordinated by the state involving interest groups and NGOs. The renaturation lead to intense controversies, as local land owners and residents were affected by rising water levels and feared damages caused by more frequent flooding events and accumulation of sediment in the river
Desealing cities 2013-2016 703
Erft Restoration 2002-2009 791
Project encourages land owners, e.g., companies and private persons to green up their paved areas in three case study cities to enhance biodiversity and to improve rain water management. Together with a central coordination point and citizen foundations, private companies and land owners as local partners, the three pilot cities of Erfurt, Wiesloch and Duisburg, redesigned paved areas to natural green spaces

To develop a structure-rich, ecologically permeable stretch of the river with regularly flooded meadows and a high potential for self-development, the dam has been removed and groynes have been built in the river bed to add morphological diversity and initiate lateral erosion

Green Roofs 2014-2019 3313

In the climate change adaption plan, the green roof strategy is part of the "Urban and landscape planning" action field for climate friendly urban development but also for rain water management. The project subsidizes greening of roofs for at least $70 \%$ of both the new buildings and existing suitable roofs

Two main sewers were rehabilitated to reduce discharge and overflows caused by heavy rain to urban water bodies. The program was part of a project on integrated stormwater management for the city of Hamburg
Stream 2006

Restoration

Green Polders

2008-2011 13917
Stream restoration measures were carried out on a few streams such as the Osterbeek (220 m section) and the Middle Bille (150 m section) to implement the Water Framework Directive. The morphology of the river bed and embankments were improved to upgrade the watercourse structure and thus create habitats for typical flora and fauna for this location

In order to combine nature conservation and flood protection, various measures were implemented, e.g., dike reinforcement, construction of a new polder canal, conversion to extensive agricultural use and creation of wet shallow water zones river to the floodplains and afforestation of a floodplain was accomplished. The biosphere reserve "Flusslandschaft Elbe-Brandenburg" initiated the project and coordinated stakeholders participation

Cold Air Corridors in Stuttgart, BadenWuertemberg
Green

Infrastructure
This project created green infrastructure corridors to reduce runoff, decrease heat waves and to purify urban air. NGOs were involved in planning processes by legal binding consultation procedures 
Table 1 continued

\begin{tabular}{|c|c|c|c|c|}
\hline Full Title (including location) & $\begin{array}{l}\text { Short Title (for } \\
\text { figures and } \\
\text { tables) }\end{array}$ & Year & $\begin{array}{l}\text { Cost } \\
\text { (USD) }\end{array}$ & Description \\
\hline Isar River Restoration in Munich, Bavaria & Isar Restoration & 2000-2011 & $\begin{array}{c}38659 \\
250\end{array}$ & $\begin{array}{l}\text { Intensive collaborative planning between numerous } \\
\text { stakeholders and a large public participation process } \\
\text { lead to new life for the Isar project. It had multiple } \\
\text { goals including the improvement of the ecological } \\
\text { status of the river, the decrease of the flood risk, and } \\
\text { the improvement of the riverscape and recreational } \\
\text { potential }\end{array}$ \\
\hline
\end{tabular}

available for 15 NBS, which totaled to approximately 1.6 million USD (Fig. 3). 70\% of the NBS received money from multiple sources (12 of 17), and most of them were funded by public subsidies (e.g., European Agricultural Fund for Rural Development) (15 of 17). 65\% of the projects we studied (11 of 17) have been implemented outside of floodplains to reduce runoff, e.g., green roofs. Only $60 \%$ of the projects required land acquisition from the private sector. Four projects included measures implemented either in the riverbed and at the riverbank or in the wider surrounding landscape.

The initial assessment of case similarity based on the hierarchical cluster analysis computed from the Gower dissimilarity matrix (Fig. 4) indicated one isolated case (e.g., Desealing cities) and the following similar cases (e.g., Lahn Restoration and stream restoration).

The MCA (Fig. 5) distributed the cases in the threedimensional space that is spanned by the first three principal components (Table 2) and further described by case typology. In particular, MCA results showed that runoff control, green roofs, and green infrastructure form a group that was negatively loaded in the first dimension, positively loaded in the second component, and negatively loaded in the third dimension. Furthermore, the results suggested that stream restoration, Lahn Restoration, and desealing cities were loaded distinctively high in the third dimension, which means that they were characterized by entities smaller than municipalities as the dominant decision level in implementation and participation, and high participation levels such as in co-decision-making and co-design. This exception appears to be in line with the hierarchical cluster analysis that identified the Lahn Restoration, and stream restoration as comparatively similar to each other but rather different to the remaining cases. This is also the case for desealing cities.

The HCPC cluster algorithm suggests a four-cluster solution (Fig. 6 and Table 3):

The type 1 cluster ("Cooperation and Incitation") contains runoff control, green roofs, and e green infrastructure.
All of these cases are at least partly funded by the city government, but only half of the cases funded by the city government are in the type 1 cluster. None of the type 1 cases implemented measures at the river bank. The most representative case is green infrastructure, as represented in Fig. 6 by the closeness of this item to the gravity center of the cluster. The stakeholder analysis (Fig. 7) showed the importance of the public-private cooperation to design and implement the NBS. Nevertheless, the planning process still resulted from a central decision center. The mean project cost of the type 1 cluster was 48600200 USD.

The type 2 cluster ("Co-design") is the biggest cluster and is composed of the Spree Restoration, polder management, the Lech Restoration, the Erft Restoration, the Ruhr Restoration, the Isar Restoration, the Lippe Restoration, and the Emscher Corridor. All these projects except the Emscher Corridor implemented measures in the riverbed, and these projects make up $80 \%$ of all the river restoration projects. All of the projects benefited from already having some land available for use since the state or municipality that owned the land required for NBS implementation was also the project leader. There were a few instances where some land acquisition was still needed. $87.5 \%$ of projects in the type 2 cluster were funded by regional agencies. All the cases that used co-design as participatory forms are type 2 projects. The cluster is best characterized by the Erft Restoration and least characterized by the Lippe Restoration. The stakeholder analysis (Fig. 7) showed that a great diversity of actors from the public, private, civil society, and NGO categories were participating in the design and implementation of the solution. The type 2 cases are the most expensive cases with a mean cost of 187773500 USD. This is more than 500 times more expensive than type 3 projects.

The type 3 cluster ("Citizen Power") is composed of the Lahn Restoration, The Stream Action Day in Hamburg, and desealing cities. The case closest to the cluster center is the Lahn Restoration. The characteristics of this cluster are the decision levels of implementation and participation that are 


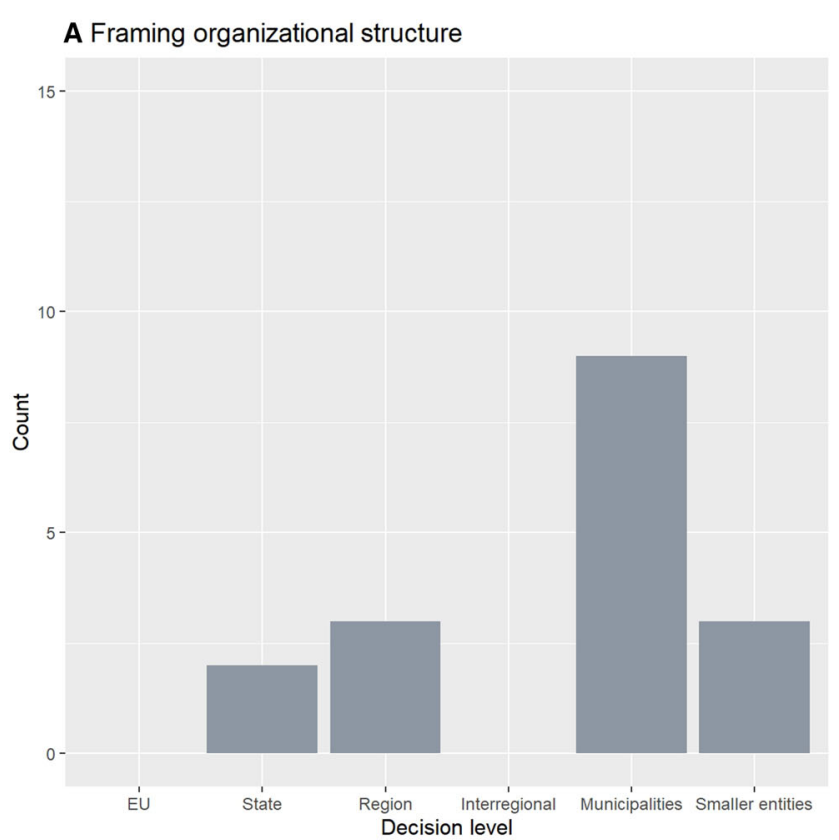

B Financing cost

C Land transactions for the implementation of NBS
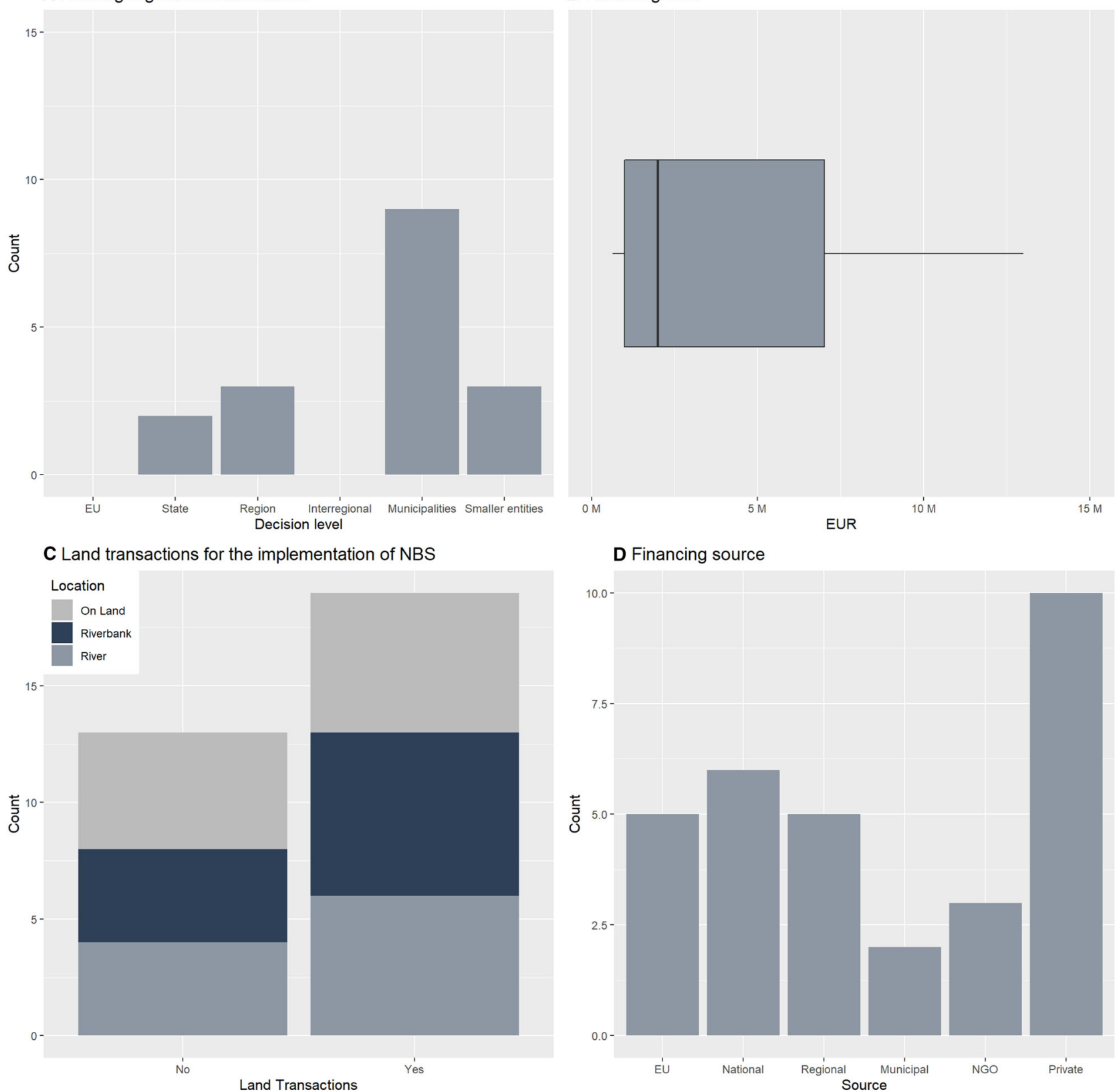

D Financing source

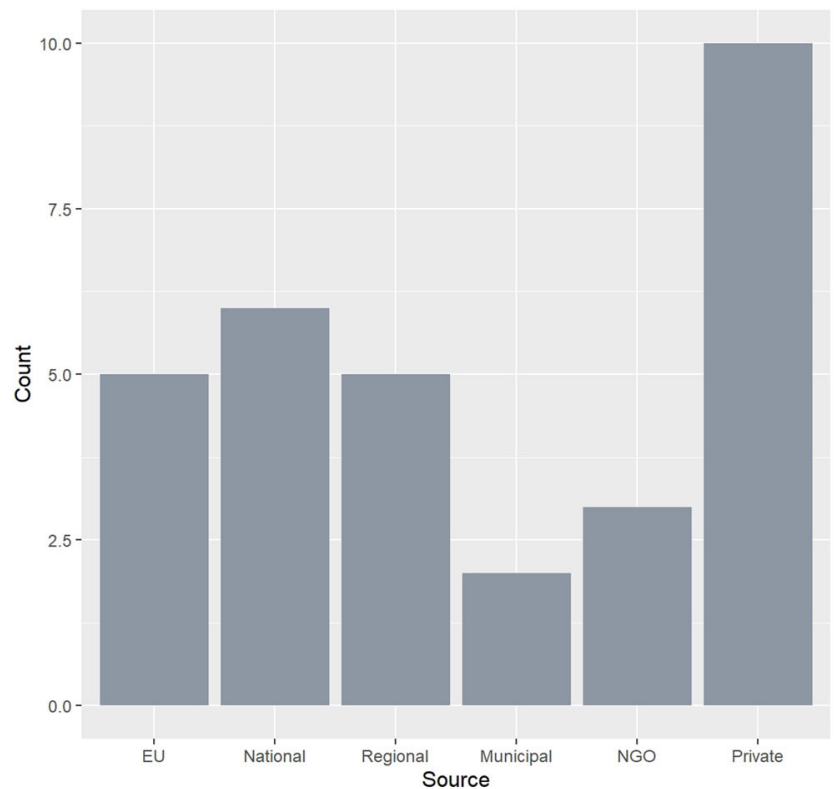

Fig. 3 Overview of cases. a Case number per decision level as framing organizational structure; b box plot of financing costs (excluding outliers); $\mathbf{c}$ land transactions for the implementation of NBS on land, riverbank, and river locations; $\mathbf{d}$ number of financing sources

composed of entities smaller than municipalities. The funding was mainlyfrom private contributions. No land acquisition is required. The stakeholder analysis (Fig. 7) showed the importance of civil society and NGOs. The type 3 cases are the cheapest with a mean cost of 353456 USD.

The type 4 cluster ("Top-Down") is composed of the Weser Restoration, the Flood Protection and Nature
Conservation at the Holter-Hammrich Polder, and dyke relocation with wetland restoration being the most characteristic case. All of the projects are decided by the EU and funded by both the EU and the state. The implementation requires land acquisition from private owners. The stakeholder analysis (Fig. 7) showed the dominance of the public component. The mean cost of type 4 projects were 10603680 USD. 


\section{Cluster Dendrogram}

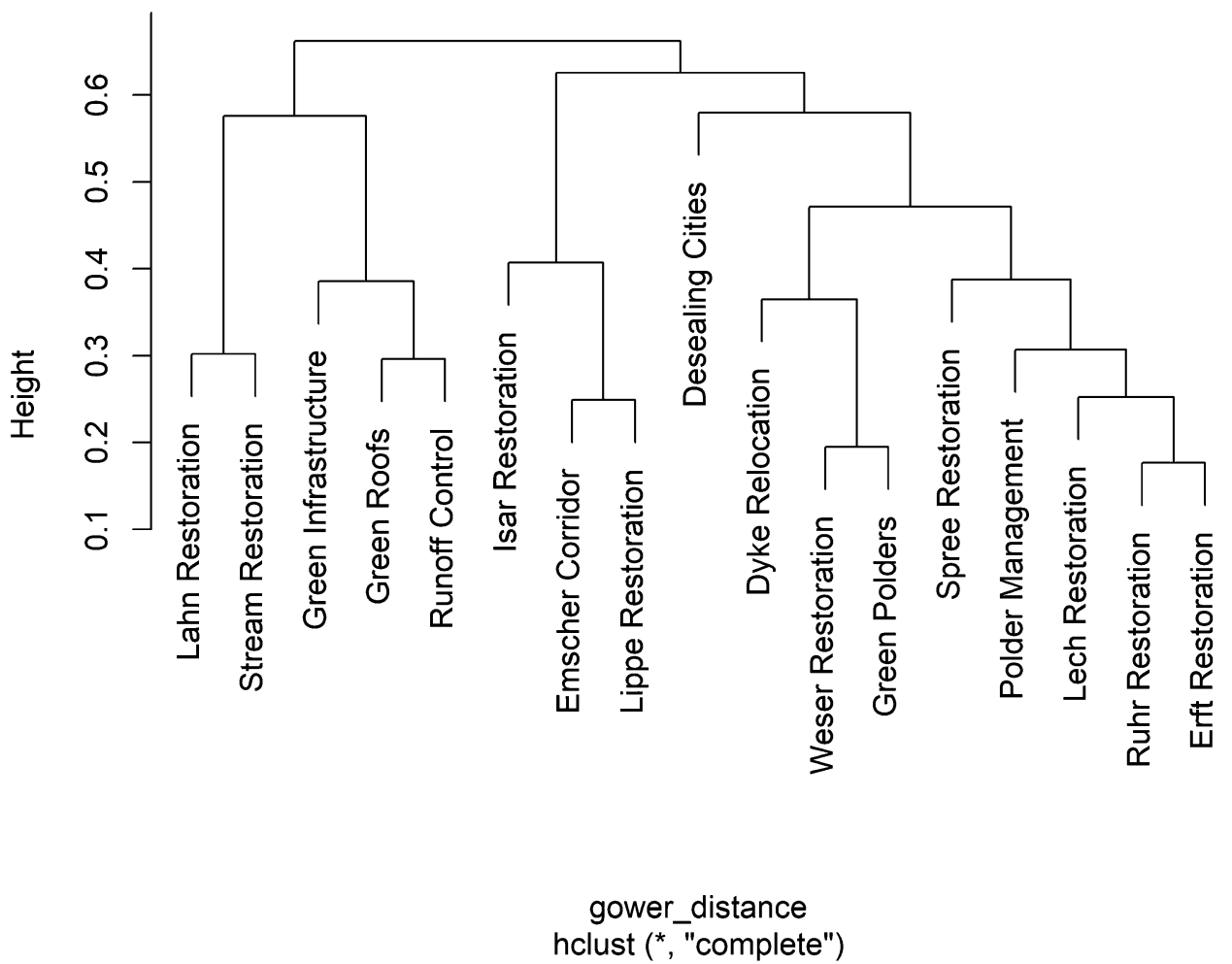

Fig. 4 Cluster dendrogram obtained through hierarchical clustering of cases using the Gower distance as a dissimilarity measure and complete linkage criterion to reveal similarity of cases, i.e., common occurrences of predictor factors

Table 2 Description of the 5 first principal components of the first three dimensions of the MCA (at $\mathrm{p}<0.05$ )

\begin{tabular}{|c|c|c|c|}
\hline Variable & Modality & $\mathrm{R} 2$ & Estimate \\
\hline \multicolumn{4}{|l|}{ 1st Dimension } \\
\hline Institutional setting of the project... & ...interplay mechanisms & 0.68 & 0.80 \\
\hline Financing source $\ldots$ & ... NGO & 0.53 & 0.56 \\
\hline Implementation at the level of $\ldots$ & $\ldots$ the state & 0.67 & 0.85 \\
\hline Participation in the decision at the level of. & $\ldots$ the state & 0.66 & 0.84 \\
\hline Lead coordinating actor ... & $\ldots$ the state & 0.63 & 0.68 \\
\hline Property rights ... & $\ldots$ other than state or municipality & 0.43 & 0.34 \\
\hline \multicolumn{4}{|l|}{ 2nd Dimension } \\
\hline Financing source $\ldots$ & ... regional funds & 0.63 & 0.37 \\
\hline Land transactions... & $\ldots$ are not necessary & 0.49 & 0.33 \\
\hline Decision level of the implementation ... & ...smaller entity than municipality & 0.63 & 0.58 \\
\hline Participation of the decision at the level of. & $\ldots$ the EU & 0.33 & 0.28 \\
\hline Participation of the decision at the level of. & ...smaller entity than municipality & 0.52 & 0.24 \\
\hline \multicolumn{4}{|l|}{ 3rd Dimension } \\
\hline Financing source... & ...private & 0.37 & 0.35 \\
\hline Decision level of the implementation... & ...smaller entity than municipality & 0.55 & 0.60 \\
\hline Participation of the decision at the level of. & ...smaller entity than municipality & 0.51 & 0.60 \\
\hline Institutional setting of the project... & ... state & 0.44 & 0.89 \\
\hline Participation lead... & ...central & 0.30 & 0.26 \\
\hline
\end{tabular}




\section{$\operatorname{Dim} 3$}
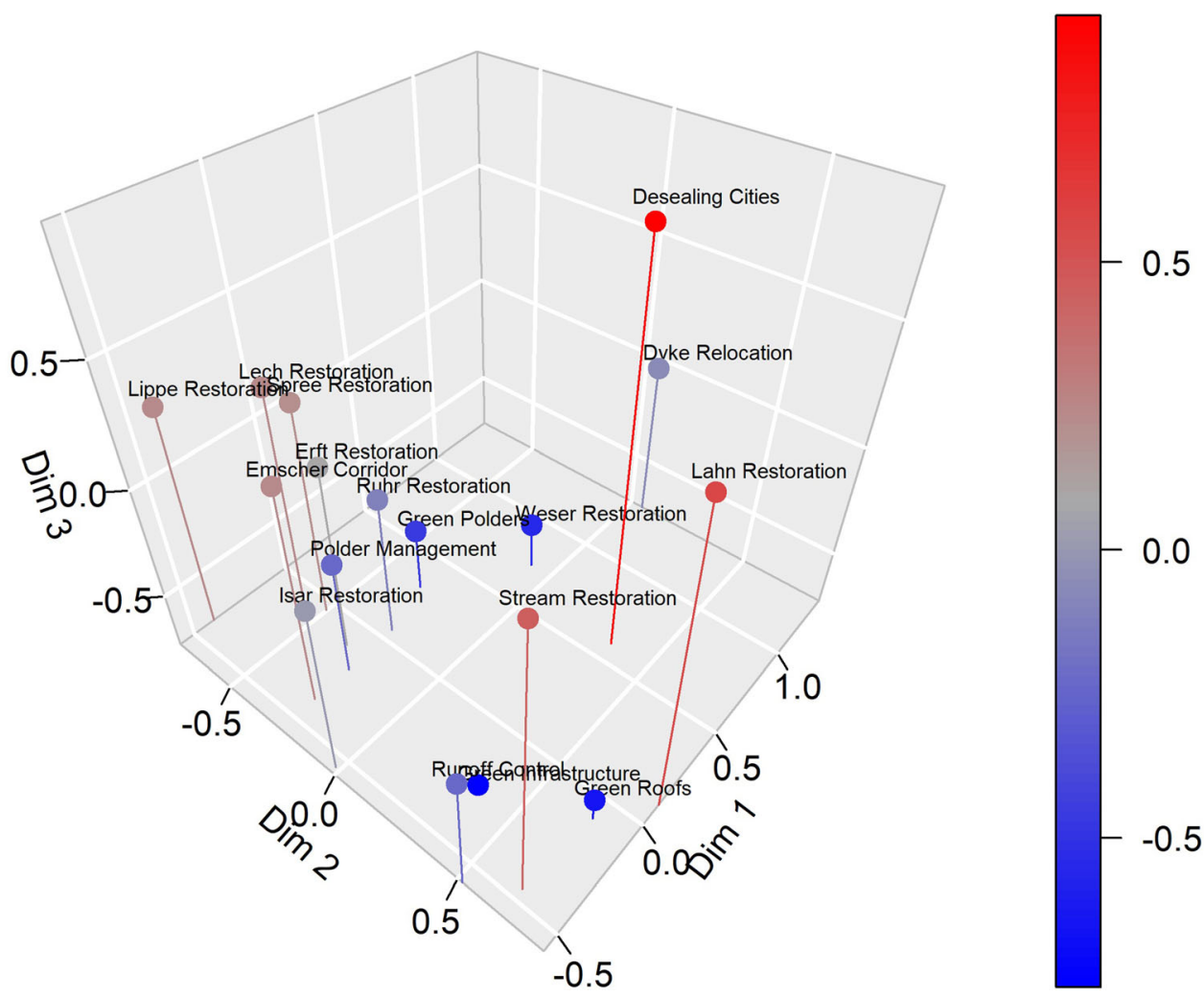

Fig. 5 Map of individuals along the first three dimensions. The color of the cases indicates the factor loading on the third component, i.e., blue individuals have negative loads on the third principal component, whereas red individuals load highly on said dimension

The qualitative comparison between the types of governance models identified and governance model types described in the literature is synthesized in Table 4. On the one hand, there were some similarities between the government model types, but on the other hand, there were also clear differences between the model types based on the observation of practices (method presented in this paper) and model types described at the theoretical level (method found in literature).

\section{DISCUSSION}

This paper has investigated governance models for the implementation of NBS for mitigating flood risk in Germany. The selection of NBS followed a systematic method, and the resulting data set showed a wide variety of implemented measures and few data on governance. Cases in each cluster share distinctive similarities in their governance features. However, the HCPC showed four governance models: (1) "cooperation and incitation", (2) "codesign", (3) "citizen power" and (4) "top-down". This mirrors the whole spectrum of participation level ranging from single information to decision making (Arnstein 1969).

The diversity of stakeholder groups and the direction of mainstreaming at the operational and institutional level differentiate the clusters. Type 1 projects contain NBS such as green roof design with a dominant goal in climate adaptation strategy while also improving flood risk mitigation. These projects intend to reduce hazard exposure more than the vulnerability of the exposed area since they are implemented in the city or in other landscapes rather than along the river. Because of property rights, many private actors are responsible or involved in the implementation of these NBS which are planned by the city government. Therefore, the linking of on-the-ground actors with the city government to implement long-term and large-scale measures aimed at hazard exposure reduction is crucial to ensure implementation. This is often the case when NBS are related to adaptive behavior such as the change in usage of existing open private green space (Wamsler et al. 2017). The opposite model is the type 3 projects. These projects illustrate how citizens can drive action and develop innovative financing models. Type 4 is different from type 1 and 3 because of the simple top-down 


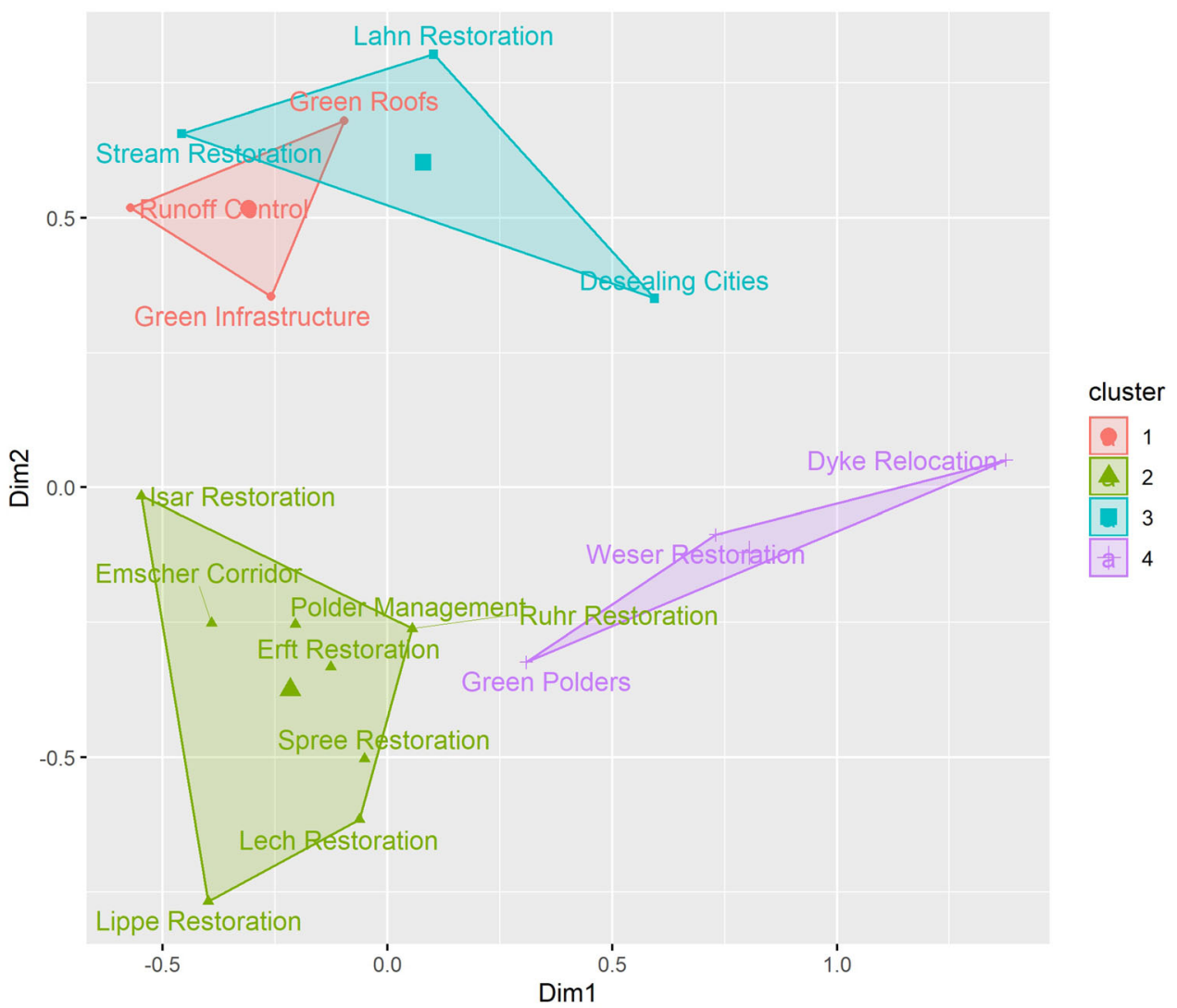

Fig. 6 Cluster solution obtained through the hierarchical clustering of principal components, suggesting four clusters as the optimal number of groups

Table 3 Main project-type characteristics to which project types are associated (at $p<0.05$ )

\begin{tabular}{|c|c|c|c|c|}
\hline Governance features & $\begin{array}{l}\text { Type } 1 \\
\text { Cooperation and } \\
\text { Initiatives }\end{array}$ & $\begin{array}{l}\text { Type } 2 \text { Co- } \\
\text { Design }\end{array}$ & Type 3 Citizen Power & Type 4 Top-Down \\
\hline $\begin{array}{l}\text { Framing and implementing } \\
\text { organisational structures }\end{array}$ & & & $\begin{array}{l}\text { Entities smaller than the municipalities as the } \\
\text { dominant implementation level }(100 \%)\end{array}$ & $\begin{array}{l}\text { Implementation under the } \\
\text { lead of the State }(70 \%)\end{array}$ \\
\hline Project coordination & State & & & \\
\hline Participation level & Central & Co-design & Citizen power & \\
\hline Institutional setting & $\begin{array}{l}\text { City government } \\
\text { and private }\end{array}$ & & $\begin{array}{l}\text { Entities smaller than the municipalities as the } \\
\text { dominant decision level }(100 \%)\end{array}$ & $\begin{array}{l}\text { EU, Decision taken at the } \\
\text { level of the State }(70 \%)\end{array}$ \\
\hline Financing model & $\begin{array}{l}\text { No regional } \\
\text { funding } \\
\text { Municipal funding } \\
(100 \%)\end{array}$ & $\begin{array}{l}\text { Regional funding } \\
\quad(100 \%)\end{array}$ & Private contributions $(70 \%)$ or Municipal & EU and State $(100 \%)$ \\
\hline $\begin{array}{r}\text { Property rights } \\
\text { constellation }\end{array}$ & $\begin{array}{l}\text { No land } \\
\text { transactions }\end{array}$ & $\begin{array}{l}\text { State or City } \\
\text { government } \\
(100 \%)\end{array}$ & & \\
\hline Localization & $\begin{array}{l}\text { River bank } \\
\quad(100 \%)\end{array}$ & River restoration & & $\begin{array}{l}\text { No implementation in the } \\
\text { river bed }\end{array}$ \\
\hline
\end{tabular}

style stakeholder constellation. This does not always mean that only one powerful entity drives NBS implementation but that other stakeholders are underrepresented. Most cases are type 2 where NBS are co-designed by complex stakeholder constellations. Type 2 projects are very expensive and rely on funding security and land 
availability from project leaders. These projects are the most comprehensive in applying the four approaches to reduce climate risks: reducing hazard exposure, reducing vulnerability of exposed area, ensuring effective response during risk and ensuring effective recovery (Wamsler et al. 2017).

Our analysis showed that NBS design and implementation resulted mostly from collaborative planning including stakeholders from single or multiple stakeholder groups, i.e., public, private, NGO, and civil society. The numerous NBS goals may be an explanation for the broad spectrum of stakeholders included in the planning and implementation (Zingraff-Hamed et al. 2019). Because of their inherent makeup, NBS can achieve these multiple goals (Raymond et al. 2017; Cohen-Shacham et al. 2019). Governance models with a large spectrum of stakeholders from different geographic and juridical levels are often regarded to be more effective in facing water issues because of their higher resilience and their capacity to deal with complex systems (Lee 2009; Wuijts et al. 2018). This study showed that these governance models are also effective for the implementation of NBS.

In line with previous studies, the 17 German cases studied are advocated at different levels (Wamsler 2015; von Wirth et al. 2019). This observation has been already made for urban parks (Buijs et al. 2019). However, the results of our study show that municipalities, citizens and NGOs, are important pieces of the stakeholder constellation that drives NBS implementation in urban as well as in rural areas. Previous studies concerning ecosystem-based climate change adaptation measures already suggest that in Germany, landscape planning is most advanced in cities in which earlier efforts in environmental planning led to multiple and decentralized decision centers (Wamsler 2015). While collaborative, interdisciplinary, and interdepartmental governance approaches are key for implementing NBS (Kabisch et al. 2016; Frantzeskaki et al. 2019), our study showed that local authorities have a crucial role in integrating NBS into location-based planning strategies. In particular, the "local champion" has a decisive political role in mitigating natural hazards (Martin et al. 2019). A comparison of ecosystem-based adaptation measures for climate change between German and Swedish cases already suggested that in Germany, committed politicians at the municipal level drive the integration of climate change mitigation measures into landscape planning and thus compensating for a lack of clear guidance from the state and regional level (Edelenbos 2005; Wamsler 2015).

In our study, we compared our results to existing governance model typologies. In contrast to these theoretical models deduced from governance theories, our method is inductive meaning that types are based on real-life governance features of various cases. Inductive methods to develop typology are also used in different fields of policy science (e.g., Mattijssen et al. 2018; Celata and Coletti 2019). We found that our typology is in line with existing governance models described in Table 4, which confirms the validity of our results on a broader scale beyond the 17 cases in Germany. Our typology is relatively close to Arnouts et al. (2012) typology, especially because at the difference of for instance Kooiman (2003) that developed three different governance models (hierarchical governance, co-governance and self-governance) along the dimension of the role of governmental and non-governmental actors, Arnouts et al. (2012) divided co-governance as closed and open co-governance. However, differences exist. Other model as for example, Pahl-Wostl's governance typology (2015) used another approach and differentiates between hierarchical, network and market governance. Compared to this governance typology, there is a difference in presence of the market dimension. Besides the market dimension however, the models are similar in terms of distinguishing between hierarchies and networks. Treib et al. (2007) seems to better address the initiator of the NBS then our typology. Finally, Vatn (2010) is based on the dimensions of the power of decision making and resource allocation and distinguished between hierarchies-based, market-based, and community-based management. Interestingly, when we compared our typology to the governance models of Vatn (2010), we found that the hybrid models with market elements were not very distinctive. This may be due to data collection limitations. Data on resource allocation, financing models, and property rights constellation were partly lacking. Therefore, the topic of market-based approaches has to be explored in future research. Specifically, business models for NBS need to be investigated whether market approaches are suitable governance models for NBS implementation.

Our systematic approach to identify a governance model typology was based on cases in Germany. However, observation of international cases shows the value of investigating a broader scale. Implemented cases included in the ReConect project show that a high exposure to risks, e.g., in the Austrian Alps, is correlated to type 4 governance models. Type 2 governance models have been institutionalized in the Netherlands for centuries but codesign in this case has led to grey infrastructure rather than NBS. Ongoing Phusicos and ReConect cases are located all around the world and intend to incorporate co-design NBS and cover the four identified types of governance models. These insights showed that although NBS can be the result of a traditional state power model, the interest for cooperation-based models and the effectiveness of these models are growing. This highlights the shift from government to governance (Edelenbos 2005). 


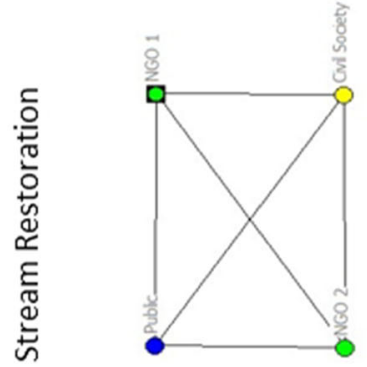

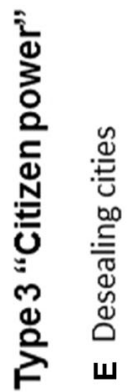

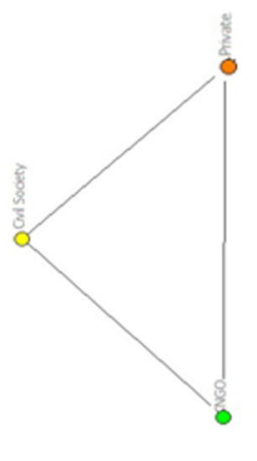

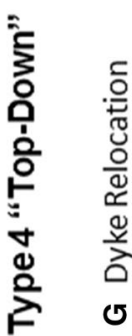

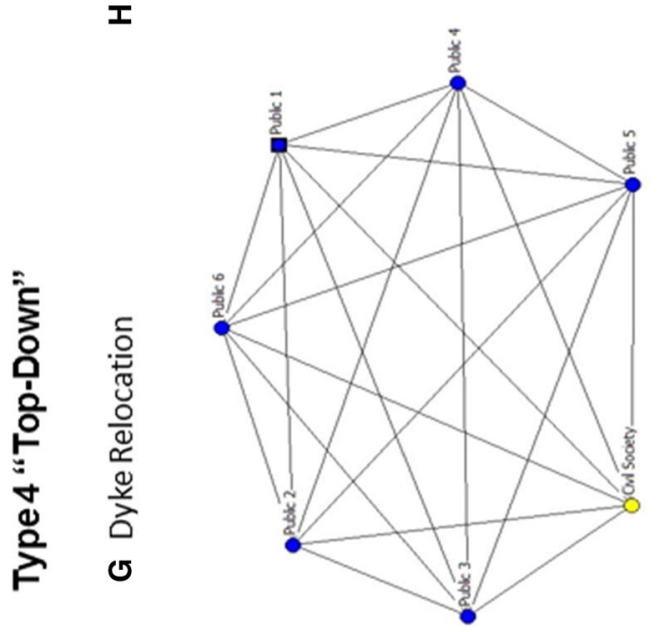

$\Xi \stackrel{\circ}{0}$

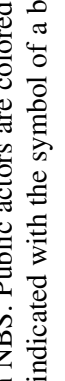

50

잉

일

ट

i

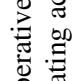

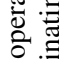

8

잉

ำ

。ํㅇㅇ

Ð.$\Xi$

ㅎํㅎ

ธิ

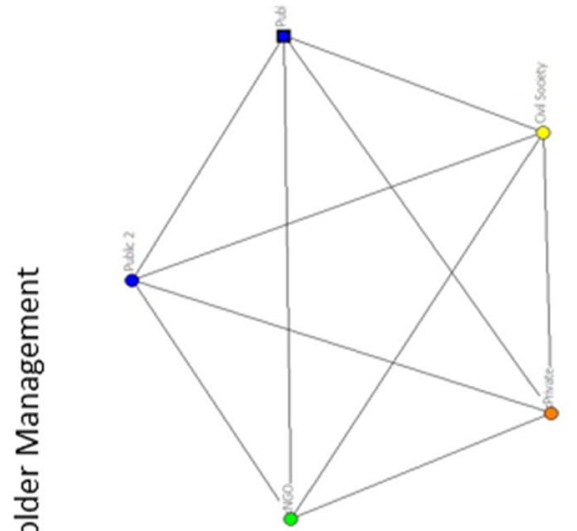

등 님

\begin{tabular}{l}
4 \\
4 \\
0 \\
\hdashline \\
$\frac{1}{0}$ \\
$\frac{1}{5}$ \\
$\infty$
\end{tabular}

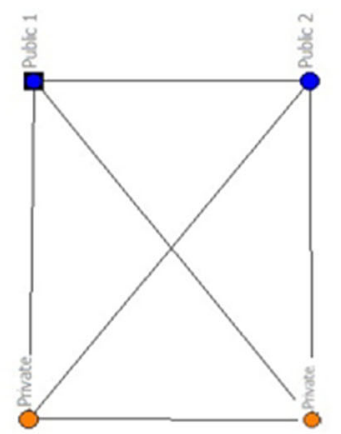

อ

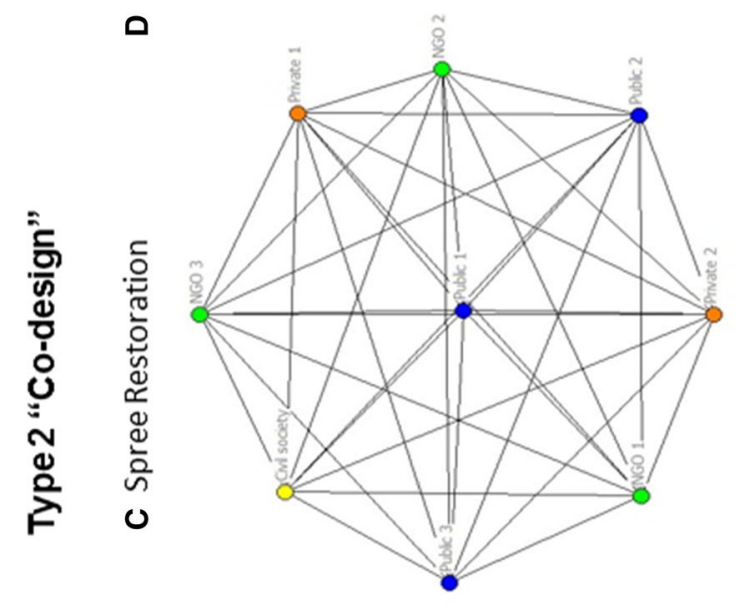

‡

ㅎํㄴ

궁

$\stackrel{0}{0}$

응

들

II

ปี

웜

흔 응

ธิ ป

䒕

宩

范

Ð

4

옹융

츨

.

的.

$\sim$ ․․

ํํㄷ용 www.kva.se/en 
Table 4 Synthesis of the main results of the governance model typology

\begin{tabular}{|c|c|c|c|c|}
\hline $\begin{array}{l}\text { Governance } \\
\text { models } \\
\text { identified }\end{array}$ & Dimensions & Description & Politics & Reference \\
\hline $\begin{array}{l}\text { Hierarchical } \\
\text { governance } \\
\text { Network } \\
\text { governance } \\
\text { Market } \\
\text { governance }\end{array}$ & $\begin{array}{l}\text { Formality of institutions and the role of state } \\
\text { versus non-state actors }\end{array}$ & $\begin{array}{l}\text { The hierarchical style is characterized by the } \\
\text { dominant role of the government, while the } \\
\text { network mode includes all forms of } \\
\text { cooperation between government and non- } \\
\text { state actors. In the market mode, the } \\
\text { government delivers services to non-state } \\
\text { actors but choices are free and ruled by } \\
\text { prices and negotiations }\end{array}$ & Water & $\begin{array}{l}\text { Pahl-Wostl } \\
\quad(2015)\end{array}$ \\
\hline $\begin{array}{l}\text { hierarchical } \\
\text { governance } \\
\text { Co- } \\
\text { governance } \\
\text { Self- } \\
\text { governance }\end{array}$ & $\begin{array}{l}\text { Role of governmental and non-governmental } \\
\text { actors }\end{array}$ & $\begin{array}{l}\text { Hierarchical governance has at one end of the } \\
\text { spectrum a top-down influence by the } \\
\text { government and at the other end, self- } \\
\text { governance where actors are not controlled } \\
\text { by government. Co-governance where public } \\
\text { and private actors interact with each other is } \\
\text { located in between the two ends }\end{array}$ & $\begin{array}{l}\text { No specific } \\
\text { politics }\end{array}$ & $\begin{array}{c}\text { Kooiman } \\
(2003)\end{array}$ \\
\hline $\begin{array}{l}\text { Hierarchical } \\
\text { governance } \\
\text { Closed co- } \\
\text { governance } \\
\text { Open co- } \\
\text { governance } \\
\text { Self- } \\
\text { governance }\end{array}$ & Actors, power and rules & $\begin{array}{l}\text { Amplification of Kooiman's spectrum by } \\
\text { dividing co-governance as closed and open } \\
\text { co-governance. Closed co-governance } \\
\text { contains a selected mixed group of actors, } \\
\text { restricted cooperation and pooled power } \\
\text { relations while open co-governance contains } \\
\text { a large mix with diffused power and flexible } \\
\text { rules of cooperation }\end{array}$ & Nature policy & $\begin{array}{l}\text { Arnouts et al. } \\
\text { (2012) }\end{array}$ \\
\hline $\begin{array}{l}\text { Coercion } \\
\text { Voluntarism } \\
\text { Targeting } \\
\text { Framework } \\
\text { regulation }\end{array}$ & $\begin{array}{l}\text { State intervention versus societal autonomy } \\
\text { but along the three dimensions of polity } \\
\text { (political form), policy (policy content) } \\
\text { and politics (political processes) }\end{array}$ & $\begin{array}{l}\text { This typology puts emphasis on the role and } \\
\text { the self-empowerment of the state and } \\
\text { integrates the European multi-level } \\
\text { governance system. Important criteria are, } \\
\text { whether legislation is binding; and whether } \\
\text { implementation is rigid }\end{array}$ & $\begin{array}{l}\text { European } \\
\text { Union }\end{array}$ & $\begin{array}{l}\text { Treib et al. } \\
\quad(2007)\end{array}$ \\
\hline $\begin{array}{l}\text { Hierarchies, } \\
\text { Markets, and } \\
\text { Community- } \\
\text { based } \\
\text { approaches }\end{array}$ & $\begin{array}{l}\text { Power of decision making and resource } \\
\text { allocation }\end{array}$ & $\begin{array}{l}\text { Hierarchies are based on command and control } \\
\text { and resource allocation occurs through } \\
\text { authority and power structures. Market- } \\
\text { based approaches are driven by the voluntary } \\
\text { exchange among individual actors, and } \\
\text { resource allocation is based on willingness to } \\
\text { pay. Community management is based on } \\
\text { cooperation among actors, and resource } \\
\text { allocation is taking into account individual } \\
\text { as well as common goals }\end{array}$ & $\begin{array}{r}\text { Ecosystem } \\
\text { Services }\end{array}$ & Vatn (2010) \\
\hline $\begin{array}{l}\text { Centralized } \\
\text { governance } \\
\text { Decentralized } \\
\text { governance } \\
\text { Public-Private } \\
\text { governance } \\
\text { Interactive } \\
\text { Governance } \\
\text { Self- } \\
\text { governance }\end{array}$ & $\begin{array}{l}\text { Actor features, institutional features and } \\
\text { feature contents }\end{array}$ & $\begin{array}{l}\text { Models are distinguished according to } \\
\text { initiating actors, stakeholder position, policy } \\
\text { level and power base (actor features); model } \\
\text { of representation, rules of interaction, and } \\
\text { mechanism of social interaction } \\
\text { (institutional features); and goals and targets, } \\
\text { instruments, policy integration, and science- } \\
\text { policy interface (features content) }\end{array}$ & $\begin{array}{l}\text { Environmental } \\
\text { governance }\end{array}$ & $\begin{array}{l}\text { Driessen et al. } \\
\quad(2012)\end{array}$ \\
\hline
\end{tabular}


Table 4 continued

\begin{tabular}{|c|c|c|c|c|}
\hline $\begin{array}{l}\text { Governance } \\
\text { models } \\
\text { identified }\end{array}$ & Dimensions & Description & Politics & Reference \\
\hline $\begin{array}{l}\text { Self- } \\
\text { governing } \\
\text { Governing by } \\
\text { provision } \\
\text { Governing by } \\
\text { authority } \\
\text { Governing } \\
\text { through } \\
\text { enabling }\end{array}$ & Government vs. other actors & $\begin{array}{l}\text { Governance modes vary according to the } \\
\text { capacity of local government and practice to } \\
\text { deliver particular forms of services and } \\
\text { resources up to the traditional forms of } \\
\text { authoritarian regulation }\end{array}$ & Climate & $\begin{array}{l}\text { Bulkeley and } \\
\text { Kern (2006) }\end{array}$ \\
\hline $\begin{array}{l}\text { Cooperation } \\
\text { and } \\
\text { Initiatives } \\
\text { Co-Design } \\
\text { Citizen Power } \\
\text { Top-down }\end{array}$ & $\begin{array}{l}\text { Framing and implementing organizational } \\
\quad \text { structures } \\
\text { Project Coordination } \\
\text { Participation level } \\
\text { Institutional setting } \\
\text { Financing model } \\
\text { Property rights, constellation and } \\
\text { localization }\end{array}$ & $\begin{array}{l}\text { Governance models range from more } \\
\text { participation and private funding to more } \\
\text { top-down ruling and state funding }\end{array}$ & $\begin{array}{c}\text { Nature-based } \\
\text { solutions }\end{array}$ & $\begin{array}{l}\text { This } \\
\text { contribution }\end{array}$ \\
\hline
\end{tabular}

To face future water governance challenges, the EU is actively encouraging type 2 governance models by funding research and action projects. The EU identified polycentric governance as a driver for successful NBS implementation (EC 2003) and provided clear guidance encouraging collaborative planning through different policies, e.g., the Flood Directive, the Water Framework Directive and the Public Participation Directive. However, some of the collaborative planning processes to co-design NBS struggle to find consensus. Many challenges (Graversgaard et al. 2017) and lessons (Zingraff-Hamed et al. 2019) from polycentric governance and NBS co-design have been identified. Further research may provide valuable insight on the success of the co-design process in different traditional planning contexts. The investigation of adaptability potential and process to more collaborative models of traditional governance constellation is especially relevant for future governance guidance.

While large-scale NBS is crucial for effectiveness, implementation remains at the level of a pilot area or at a local government scale (Hartmann and Spit 2016). However, the Flood and the Water Framework Directives require management plans that exceed the municipal level. In Germany, two historical governance barriers need to be overcome. First, flood protection strategy historically relied on the regional authorities which did not have jurisdiction over the river catchment area or river basin district (Hartmann and Spit 2016; Brödner 2019). Second, stakeholders are accustomed to implementing technical solutions that address local risks (Lünenbürger 2006; Brödner 2019). A paradigm change is urgently needed to implement largescale solutions as requested by the EU directives.

Our study has few limitations. This investigation did not identify how local authorities integrate NBS into their plans, policies and strategies. Furthermore, we did not identify the best governance model. Moreover, the results depend on the methods applied. It should be noted that we only used NBS documented in online databases and consequently, only successfully implemented solutions. It is probable that not all existing NBS were included. We also relied on the information presented in these databases, which provided a relatively small amount of information on governance issues. Our data analysis applied standard statistical methods that have already been proven effective in identifying project typologies (Zingraff-Hamed et al. 2017a). However, the relatively low number of cases and the large number of variables addressed influenced the outcomes of the analysis. Finally, the study did not try to identify the characteristics of a successful water governance structure.

\section{CONCLUSION}

This paper investigates governance model that led to 17 NBS implementation in Germany to mitigate flood risk and provides important insights for researchers and practitioners interested in investigating, successfully designing, and implementing NBS. First, this contribution presents a novel attempt in clustering governance models in an inductive 
manner instead of deductive one. This investigation shows that different models lead to NBS implementation and suggests that no "one-size-fits-all" model can be identified. However, an important commonality between the governance models exists, namely, the inclusion of different stakeholder groups. This suggests that collaborative governance approaches are a key factor for successful implementation of NBS.

Second, this paper suggests that a high degree of cooperation between the stakeholders improves NBS implementation potential. The EU intends to encourage NBS implementation via polycentric governance. However, local, historical, and cultural differences in governance approaches cause difficulties in implementing collaborative planning and context conditions seem to influence the governance models applied. It is extremely important that NBS research projects analyze governance models systematically. Future governance will be challenged to adapt traditional governance models to implement large-scale solutions with higher number of stakeholders.

Finally, this investigation identifies municipalities, citizens, and NGOs as crucial pieces of the stakeholder constellation to NBS design and implementation. Many empirical but few evidence-based work on governance structures for NBS underscore these results. This contribution addresses this gap. Interestingly, while the importance of on-the-ground stakeholders for the design and implementation process of NBS may sound as common sense, in many governance systems, they are not yet recognized. We hope that with the evidence that this contribution provides, planners and managers will be encouraged to take up the ideas of more inclusive governance models in practice.

Acknowledgements This contribution is a result of the SmartNBS research task force between PHUSICOS research group of the Technical University of Munich, RECONECT research group of the Helmholtz Centre for Environmental Research Leipzig (UFZ), the Plansmart Junior Research group at Ruhr University Bochum, and Leibniz Centre for Agricultural Landscape Research (ZALF) in Müncheberg. AZH, GL, and JH were funded by the project PHUSICOS that has received funding from the European Union's Horizon 2020 research and innovation program under grant agreement No 776681. FH was funded by the project RECONECT that has received funding from the European Union's Horizon 2020 research and innovation program under Grant Agreement No 776866. MB, MS, $\mathrm{CA}$, and BS were funded by the German Federal Ministry for Education and Research (Bundesministerium für Bildung und Forschung BMBF) through a grant for the PlanSmart research group (grant no: 01UU1601A and B) as part of the funding priority "Social-Ecological Research" within the Research for Sustainability Program (FONA ${ }^{3}$ ). SS was funded by the project CONNECTING NATURE funded by the Horizon 2020 Framework Programme of the European Union under Grant Agreement No 730222 and the project CLEARING HOUSE funded by the European Union's Horizon 2020 Research and Innovation Program under Grant Agreement No 821242. We thank all the data providers and external reviewers. We like to express sincere appreciation to all who contributed time, experience, and knowledge to support the development of this contribution. The authors especially like to thank the stakeholders who took time for responding to our questions.

Funding Open Access funding enabled and organized by Projekt DEAL.

Open Access This article is licensed under a Creative Commons Attribution 4.0 International License, which permits use, sharing, adaptation, distribution and reproduction in any medium or format, as long as you give appropriate credit to the original author(s) and the source, provide a link to the Creative Commons licence, and indicate if changes were made. The images or other third party material in this article are included in the article's Creative Commons licence, unless indicated otherwise in a credit line to the material. If material is not included in the article's Creative Commons licence and your intended use is not permitted by statutory regulation or exceeds the permitted use, you will need to obtain permission directly from the copyright holder. To view a copy of this licence, visit http://creativecommons. org/licenses/by/4.0/.

\section{REFERENCES}

Arnouts, R., M. van der Zouwen, and B. Arts. 2012. Analysing governance modes and shifts - Governance arrangements in Dutch nature policy. Forest Policy and Economics 16: 43-50.

Arnstein, S.R. 1969. A ladder of citizen participation. Journal of the American Planning Association 35: 216-224.

Beniston, M. 2007. Linking extreme climate events and economic impacts: Examples from the Swiss Alps. Energy Policy 35: $5384-5392$.

Brödner, R. 2019. Reformvorschlag für den Hochwasserschutz in Deutschland. Chemnitz: Technical University of Chemnitz.

Buijs, A., R. Hansen, S. Van der Jagt, B. Ambrose-Oji, B. Elands, E. Lorance Rall, T. Mattijssen, S. Pauleit, et al. 2019. Mosaic governance for urban green infrastructure: Upscaling active citizenship from a local government perspective. Urban Forestry \& Urban Greening 40: 53-62.

Bulkeley, H., and K. Kern. 2006. Local government and the governing of climate change in Germany and the UK. Urban Studies 43: 2237-2259.

Celata, F., and R. Coletti. 2019. Enabling and disabling policy environments for community-led sustainability transitions. Regional Environmental Change 19: 983-993.

CoB. 2007. Management Plan for the Waterways in Bergen/ Forvaltningsplan Vassdragene i Bergen. Bergen: City of Bergen.

Cohen-Shacham, E., A. Andrade, J. Dalton, N. Dudley, M. Jones, C. Kumar, S. Maginnis, S. Maynard, et al. 2019. Core principles for successfully implementing and upscaling Nature-based Solutions. Environmental Science \& Policy 98: 20-29.

Cohen-Shacham, E., G. Walters, C. Janzen, and S. Maginnis. 2016. Nature-based solutions to address global societal challenges. Gland: International Union for Conservation of Nature.

De Paola, F., M. Giugni, F. Pugliese, and P. Romano. 2018. Optimal design of LIDs in urban stormwater systems using a harmonysearch decision support system. Water Resources Management 32: 4933-4951. 
Doocy, S., A. Daniels, S. Murray, and T. Kirsch. 2013. The human impact of floods: A historical review of events 1980-2009 and systematic literature review. PLoS Currents Disasters 1: 5.

Driessen, P.P.J., C. Dieperink, F. van Laerhoven, H.A.C. Runhaar, and W.J.V. Vermeulen. 2012. Towards a conceptual framework for the study of shifts in modes of environmental governance Experiences from the Netherlands. Environmental Policy and Governance 22: 143-160.

EC. 2003. Guidance document no. 3: Common implementation strategy for the water framework directive (2000/60/EC). Luxemburg: European Commission.

EC. 2014. Study on economic and social benefits of environmental protection and resource efficiency related to the european semester. Brussel: DG Environment.

EC. 2015a. Call for ideas for large-scale demonstration projects Outcome report HORIZON 2020 'Climate action, environment, resource efficiency and raw materials'. Brussel: European Commission.

EC. 2015b. Nature-based solutions \& re-naturing cities. Brussel: European Commission.

EC. 2020. Towards an EU Research and Innovation policy agenda for Nature-Based Solutions \& Re-Naturing Cities. Brussel: EU.

Edelenbos, J. 2005. Institutional Implications of Interactive Governance: Insights from Dutch Practice. Governance 18: 111-134.

EEA. 2016. Flood risk in Europe: the long-term outlook. Online consulted the 5 March 2020 (www.eea.europa.eu): EEA. https:// www.eea.europa.eu/highlights/flood-risk-in-europe-2013.

Eggermont, H., E. Balian, J.M.N. Azevedo, V. Beumer, T. Brodin, J. Claudet, and B. Fady. 2015. Nature-based solutions: New influence for environmental management and research in Europe. GAIA - Ecological Perspectives for Science and Society 24: $243-248$

Ershad Sarabi, S., Q. Han, A.G.L. Romme, B. de Vries, and L. Wendling. 2019. Key enablers of and barriers to the uptake and implementation of nature-based solutions in urban settings: A review. Resources 8: 121.

Frantzeskaki, N., T. McPhearson, M.J. Collier, D. Kendal, H. Bulkeley, A. Dumitru, C. Walsh, K. Noble, et al. 2019. Nature-based solutions for urban climate change adaptation: Linking science, policy, and practice communities for evidencebased decision-making. BioScience 69: 455-466.

Gower, J.C. 1971. A general coefficient of similarity and some of its properties. Biometrics 27: 857-874.

Graversgaard, M., B.H. Jacobsen, C. Kjeldsen, and T. Dalgaard. 2017. Stakeholder engagement and knowledge co-creation in water planning: Can public participation increase cost-effectiveness? Water 9: 191.

Greenacre, M. 2006. From Simple to Multiple Correspondence Analysis. In Multiple correspondence analysis and related methods, statistics in the social and behavioral sciences series, ed. M. Greenacre, 3-40. Boca Raton: Academic Press.

Haine, K. 2014. Stadsvernieuwing Groene Singel. Antwerpen: Gemeente Antwerpen.

Hajat, S., K.L. Ebi, R.S. Kovats, B. Menne, S. Edwards, and A. Haines. 2005. The Human Health Consequences of Flooding in Europe: a Review. In Extreme Weather Events and Public Health Responses, ed. W. Kirch and B.R. Menne. Berlin: Springer.

Hartmann, T., and T. Spit. 2016. Legitimizing differentiated flood protection levels - Consequences of the European flood risk management plan. Environmental Science \& Policy 55: 361-367.

Husson, F., S. Le, and J. Pages. 2017. Exploratory multivariate analysis by example using $R$. Boca Raton: Academic Press.
Junk, W., P.B. Bayley, and R.E. Sparks. 1989. The flood pulse concept in river-floodplain systems. Canadian Journal of Fisheries and Aquatic Sciences 106: 110-127.

Kabisch, N., N. Frantzeskaki, S. Pauleit, S. Naumann, M. Davis, M. Artmann, D. Haase, S. Knapp, et al. 2016. Nature-based solutions to climate change mitigation and adaptation in urban areas perspectives on indicators, knowledge gaps, barriers, and opportunities for action. Ecology and Society 21: 2.

Kooiman, J. 2003. Governing as governance. London: SAGE Publications Ltd.

Le, S., J. Josse, and F. Husson. 2008. FactoMineR: A package for multivariate analysis. Journal of Statistical Software 25: 1-18.

Lee, M. 2009. Law and governance of water protection policy. In $E U$ environmental governance, ed. J. Scott. Oxford: Oxford University Press.

Lünenbürger, B. 2006. The economics of river flood management: A challenge for the federal organization? Dissertation. Heidelberg: Ruprecht-Karls-Universität.

Maechler, M., P. Rousseeuw, A. Struyf, M. Hubert and K. Hornik. 2019. CLUSTER: Cluster Analysis Basics and Extensions. $R$ package version 2.1.0.

Martin, J. 2019. Governance innovation through nature-based solutions. Laxenburg: IIASA.

Martin, J., J. Bayer, W. Liu, and A. Scolobig. 2019. Delivrable 5.1: $N B S$ in-depth case study analysis of the characteristics of successful governance models. Vienna: EU.

Mattijssen, T., A. Buijs, and B. Elands. 2018. The benefits of selfgovernance for nature conservation: A study on active citizenship in the Netherlands. Journal for Nature Conservation 43: $19-26$.

Mayring, P. 2007. Qualitative inhaltsanalyse. Weinheim: Beltz.

Nesshöver, C., T. Assmuth, K.N. Irvine, G.M. Rusch, K.A. Waylen, B. Delbaere, D. Haase, L. Jones-Walters, et al. 2017. The science, policy and practice of nature-based solutions: An interdisciplinary perspective. Science of the Total Environment 579: 1215-1227.

Newig, J., D. Schulz, and N.W. Jager. 2016. Disentangling puzzles of spatial scales and participation in environmental governance The case of governance re-scaling through the European Water Framework Directive. Environmental Management 58: 998-1014.

Pahl-Wostl, C. 2015. Governance modes. In Water governance in the face of global change - From understanding to transformation, ed. C. Pahl-Wostl, 85-96. Bern: Springer International Publishing.

Pahl-Wostl, C. 2019. The role of governance modes and metagovernance in the transformation towards sustainable water governance. Environmental Science \& Policy 91: 6-16.

Raymond, C.M., N. Frantzeskaki, N. Kabisch, P. Berry, M. Breil, M.R. Nita, D. Geneletti, and C. Calfapietra. 2017. A framework for assessing and implementing the co-benefits of nature-based solutions in urban areas. Environmental Science \& Policy 77: 15-24.

Sadowska-Dubicka, E. 2015. Biala river will writhe again, new ponds will be created. Regulating the river starts this year. https://biala. gmina.pl/1617/rewitalizacja-miasta.html (accessed 2020.06.21).

Schröter, B., C. Meyer, C. Mann, and C. Sattler. 2019. Societal response, governance, and managing ecosystem service risks. In Atlas of ecosystem services: Drivers, risks, and societal responses, ed. M. Schröter, S. Klotz, R. Seppelt, and C. Baessler, 327-333. Cham: Springer International Publishing.

Treib, O., H. Bähr, and G. Falkner. 2007. Modes of governance: Towards a conceptual clarification. Journal of European Public Policy 14: 1-20. 
UN. 2018. The United Nations World Water Development Report 2018: Nature-based solutions for water. Paris: United Nations World Water Assessment Programme.

Van de Kreek, C., and M.A. Etienne. 2012. Grand Parc Garonne: Plan guide. Toulouse: Grand Toulouse.

Vatn, A. 2010. An institutional analysis of payments for environmental services. Ecological Economics 69: 1245-1252.

von Wirth, T., L. Fuenfschilling, N. Frantzeskaki, and L. Coenen. 2019. Impacts of urban living labs on sustainability transitions: Mechanisms and strategies for systemic change through experimentation. European Planning Studies 27: 229-257.

Wamsler, C. 2015. Mainstreaming ecosystem-based adaptation: Transformation toward sustainability in urban governance and planning. Ecology and Society 20: 2.

Wamsler, C., S. Pauleit, T. Zölch, and A. Mascarenhas. 2017. Mainstreaming Nature-Based Solutions for Climate Change Adaptation in Urban Governance and Planning. In Nature-based solutions to climate change adaptation in urban areas, ed. K. Nadja, J. Stadler, and A. Bonn. Cham: Springer.

Wuijts, S., P.P.J. Driessen, and H.F.M.W. Van Rijswick. 2018. Towards more effective water quality governance: A review of social-economic, legal and ecological perspectives and their interactions. Sustainability 10: 914.

Zingraff-Hamed, A., S. Greulich, S. Pauleit, and K.M. Wantzen. 2017a. Urban and rural river restoration in France: A typology. Restoration Ecology 25: 994-1004.

Zingraff-Hamed, A., S. Greulich, K.M. Wantzen, and S. Pauleit. 2017b. Societal drivers of European Water Governance: A comparison of urban river restoration practices in France and Germany. Water 9: 206.

Zingraff-Hamed, A., J. Martin, G. Lupp, J. Linnerooth-Bayer, and S. Pauleit. 2019. Designing a resilient waterscape using a living lab and catalyzing polycentric governance. Landscape Architecture Frontiers 7: 12-31.

Publisher's Note Springer Nature remains neutral with regard to jurisdictional claims in published maps and institutional affiliations.

\section{AUTHOR BIOGRAPHIES}

Aude Zingraff-Hamed $(\square)$ is a research associate and lecturer at the Technical University of Munich, Chair for Strategic Landscape Planning and Management. Her research focus are river restoration, urban studies, nature-based solution, hydro-meteorological risk, climate change, water governance, ecosystem-based management, nature conservation, recreational uses, and socio-ecological system. Address: Technical University of Munich, Chair for Strategic Landscape Planning and Management, Emil-Ramann-Str. 6, 85354 Freising, Germany.

e-mail: aude.zingraff-hamed@tum.de

Frank Hüesker is a post-doc at the Helmholtz-Centre for Environmental Research in Leipzig. His research interests include water governance, micropollutants, nature-based solutions, and water-energy-food nexus.

Address: Helmholtz Centre for Environmental Research, Permoserstr. 15, 04318 Leipzig, Germany.

e-mail: frank.hueesker@ufz.de

Christian Albert is Professor for Environmental Analysis and Planning in Metropolitan Regions at Ruhr University Bochum, Institute of Geography. His research interests include theories and methods of landscape planning, ecosystem services, and sustainability sciences.
Address: Ruhr-Universität Bochum, Institute of Geography, Universitätsstr. 150, 44805 Bochum, Germany.

e-mail: christian.albert@rub.de

Mario Brillinger is a doctoral candidate at Viadrina University Frankfurt (Oder) and researcher at Ruhr University Bochum, Institute of Geography. He holds a Master's degree in agricultural science focusing on resource management and environmental economics. His research interests include theories and methods of collective decisionmaking, water governance research, and qualitative social science. Address: Ruhr-Universität Bochum, Institute of Geography, Universitätsstr. 150, 44805 Bochum, Germany.

e-mail: brillinger@umwelt.uni-hannover.de

Joshua Huang is a research assistant at the Technical University of Munich. His research interests include risk analysis and assessment, risk mitigation, social and ecological urban river restoration, and flood management climate change mitigation.

Address: Technical University of Munich, Chair for Strategic Landscape Planning and Management, Emil-Ramann-Str. 6, 85354 Freising, Germany.

e-mail: Josh.J.Huang@gmail.com

Gerd Lupp is a research associate at the Technical University of Munich and received his Ph.D. in forest sciences. His research interests include participatory processes, climate change and climate adaptation, assessment of ecosystem services, nature-based recreation, renewable energies, nature conservation, and sustainable forest management practices.

Address: Technical University of Munich, Chair for Strategic Landscape Planning and Management, Emil-Ramann-Str. 6, 85354 Freising, Germany.

e-mail: gerd.lupp@tum.de

Sebastian Scheuer is a post-doc in geography at the HumboldtUniversität zu Berlin. His research includes nature-based solutions for climate change adaptation in urban areas with special attention to Urban Forests, climate change impact assessment, multi-criteria risk assessment, natural hazard research, flooding in particular, and quantitative and semi-qualitative analysis of global patterns and processes of urbanization.

Address: Humboldt-University Berlin, 10099 Berlin, Germany.

e-mail: sebastian.scheuer@geo.hu-berlin.de

Mareen Schlätel is a research assistant at at the Leibniz University Hannover for the junior research group PlanSmart. Her research interests include nature-based solution, water governance, environmental planning, and river restoration.

Address: Ruhr-Universität Bochum, Institute of Geography, Universitätsstr. 150, 44805 Bochum, Germany.

e-mail: mareen.schlaetel@stud.uni-hannover.de

Barbara Schröter is a post-doc at the Leibniz Centre for Agricultural Landscape Research (ZALF) in the working group "Governance of Ecosystem Services". Her research interests include social-ecological research, governance and institutional analysis, social network analysis, and environmental justice.

Address: Leibniz Centre for Agricultural Landscape Research, Working Group "Governance of Ecosystem Services", Eberswalder Str. 84, 15374 Müncheberg, Germany.

e-mail: Barbara.Schroeter@zalf.de 